\title{
Phytochemical and Antioxidant Test of Binahong (Anredera cordifolia (Tenore) Steenis) Leaves Ethanol Extract
}

\section{Fensia Analda Souhoka*, Imanuel Berly Delvis Kapelle, Elisabeth Sihasale}

Jurusan Kimia, Fakultas Matematika dan Ilmu Pengetahuan Alam, Universitas Pattimura, Ambon, 97233, Indonesia

INFO ARTIKEL

\begin{tabular}{l}
\hline Diterima 06 Maret 2021 \\
Disetujui 26 April 2021 \\
\hline Key word: \\
Antioxidant \\
Phytochemical \\
Binahong \\
Anredera cordifolia \\
DPPH \\
\hline Kata kunci: \\
Antioksidan \\
Fitokimia \\
Binahong \\
Anredera cordifolia \\
DPPH \\
\hline
\end{tabular}

\author{
A B S T R A C T
}

Binahong Anredera cordifolia (Tenore) Steenis leaves contain chemical compounds that can be used as antioxidants. This study aims to examine the phytochemical and antioxidant activity of the ethanol extract of binahong leaves. Binahong leaves were extracted using the maceration method with an ethanol solvent. The phytochemical test showed that the ethanol extract of binahong leaves contained phenolic compounds, flavonoids, alkaloids, and tannins to have potential antioxidants. The antioxidant activity test was carried out using the DPPH method and absorbance measurement with a UV-Vis spectrophotometer at a wavelength of $517 \mathrm{~nm}$. The results showed that the ethanol extract of binahong leaves had strong antioxidant activity, as evidenced by the IC 50 value of $87.423 \mu \mathrm{g} / \mathrm{mL}$.

*fensia@fmipa.unpatti.ac.id

\section{Introduction}

Binahong is cultivated as herbal medicine, planted in pots, in the yard, or garden. Binahong leaves are often used as a traditional medicine to heal burns, rheumatism, gout, lack of appetite, nosebleeds, inflammation of the kidneys, colitis, and cancer. However, the binahong plant's benefits have not been widely known in Indonesian society [1]. Binahong leaves contain saponins, tannins, flavonoids, alkaloids, and polyphenols with antioxidant properties [2].

Antioxidants have an important role to play in maintaining health. It is due to the ability of antioxidants to scavenge free radicals. Free radicals are highly reactive because they have one or more unpaired electrons. Reactive oxygen compounds are produced continuously in the human body due to normal metabolic processes [3].

Synthetic antioxidants such as butylated hydroxytoluene (BHT) and butylated hydroxyanisole (BHA) have side effects on our health [4]. The side effect has spurred researchers to explore natural materials as a source of antioxidants. Generally, natural antioxidants are phenolic compounds scattered throughout the plant, both in the roots, stems, leaves, seeds, fruits, and flowers. Natural antioxidants from plants are polyphenols (phenolic acids, flavonoids, anthocyanins, lignans, and stilbene), carotenoids (xanthophyll and carotene), and vitamins (vitamins E and C) [5].

Several natural-based antioxidants have been studied. The methanol extract of banyan fruit has an $\mathrm{IC}_{50}$ of $40.36 \mu \mathrm{g} / \mathrm{mL}$ against $\mathrm{DPPH}$ [6]. The IC50 of the methanol extract of Kesumba Keling seeds was 69.425 ppm [7]. Ethanolic extract of binahong possesses total antioxidants of $4.25 \mathrm{mmol} / 100 \mathrm{~g}$ (fresh) and $3.68 \mathrm{mmol} / 100 \mathrm{~g}$ (dry) [3]. Binahong leaf ethyl acetate extract had an $\mathrm{IC}_{50} 68.07 \mu \mathrm{g} / \mathrm{mL}$ [8]. EC50 of binahong tuber flavonoid extract was $178.60 \mathrm{mg} / \mathrm{L}$, and $70 \%$ ethanol extract was $298.10 \mathrm{mg} / \mathrm{L}$ [9].

This study aimed to determine the chemical content and antioxidant power of binahong leaf ethanol extract. Binahong leaf 
extract was obtained by maceration using ethanol. The antioxidant activity test was carried out in-vitro with the DPPH (1,1diphenyl-2-picrylhydrazil) method. The DPPH method is often used for testing the antioxidant activity of several natural compounds because this method is relatively easy and simple compared to other methods [10].

\section{Materials and Methods}

\section{Materials}

The materials used in the study were binahong (Anredera cordifolia (Tenore) Steenis) leaves, 1,1-diphenyl-2-picrylhydrazyl (DPPH), $96 \%$ of ethanol, $\mathrm{FeCl}_{3}, \mathrm{HCl}, \mathrm{Mg}$ powder, distilled water, Mayer's reagent, and quercetin. All the chemicals were purchased from Merck with pro analysis grade.

\section{Sample preparation}

Binahong leaves were taken, washed, sliced into small pieces, dried in an oven at $105{ }^{\circ} \mathrm{C}$ for 5 hours until a constant weight was calculated for the moisture content. The dry sample was mashed and sieved until a powder was obtained.

\section{Procedure}

\section{Sample Extraction}

The $10 \mathrm{~g}$ of binahong leaf powder was put into an Erlenmeyer and added $200 \mathrm{~mL}$ of $96 \%$ ethanol until the sample was immersed and then macerated for 24 hours. The filtrate is filtered and evaporated using a rotary evaporator. The binahong leaf ethanol extract obtained was weighed and performed a phytochemical test.

\section{Phytochemical test}

The phytochemical test is a preliminary test for the ethanol extract of binahong leaves, including phenolic, flavonoid, tannin, and alkaloid tests.

\section{Preparation of test solutions}

The ethanol extract of binahong leaves as much as $0.5 \mathrm{~g}$ was dissolved in ethanol $96 \%$ in a $10 \mathrm{~mL}$ volumetric flask.

\section{Phenolic test}

The $2 \mathrm{~mL}$ sample extract was put into a test tube added $5 \mathrm{~mL}$ of ethanol, and two drops of $2 \% \mathrm{FeCl}_{3}$ were added (positive if it produces a dark blue color) [11].

\section{Flavonoid test}

A total of $2 \mathrm{~mL}$ of binahong leaf extract was added with $1 \mathrm{~mL}$ of $1 \% \mathrm{HCl}$ into a test tube, then added a little Mg powder (positive if a yellow color is formed in the presence of flavonoids) [12].

\section{Tannin test}

Ethanol extract $2 \mathrm{~mL}$ was dissolved in $1 \mathrm{~mL}$ of distilled water and brought to a boil. Then filtered and the filtrate is added 2 drops of $\mathrm{FeCl}_{3} 1 \%$ and shaken (positive if it produces a brown color) [13].

\section{Alkaloid test}

$2 \mathrm{~mL}$ of the sample extract was added with $5 \mathrm{~mL}$ of ethanol. Then added with Mayer's reagent drop by drop (positive for pink color) [14].

\section{Preparation of $40 \mathrm{ppm}$ DPPH solution}

A total of $0.01 \mathrm{~g}$ of DPPH is put into a $250 \mathrm{~mL}$ measuring flask, then ethanol is added to the limit mark. The solution is used immediately and is kept at a low temperature and protected from light [8].

\section{Determination of the maximum DPPH wavelength}

A total of $5 \mathrm{~mL}$ of DPPH solution were observed for their absorption in the wavelength range of 400-600 nm using ethanol blanks.

Determination of DPPH free radical scavenging activity.

A total of $2 \mathrm{mg}$ of ethanol extract of binahong leaf was made into a solution with 10 , 20, 30, 40, 50, 60, 70, and $80 \mathrm{ppm}$. Quercetin comparison solution was made with a concentration of 2.5; 5.0; 10; 15; 20; and 25 ppm. Each test solution of $1 \mathrm{~mL}$ was put into a test tube, and $2 \mathrm{~mL}$ of $40 \mathrm{ppm}$ DPPH solution were added, then left to stand for 30 minutes at room temperature. The absorbance measurement was carried out at a wavelength of $517 \mathrm{~nm}$ using a UV-Vis spectrophotometer [15]. The test was carried out with twice measurements. Furthermore, the $\mathrm{IC}_{50}$ value is calculated based 
on the regression equation obtained.

\section{Results and Discussions Sample Preparation}

The moisture content of the binahong leaf samples was $54.805 \%$. The high and low water content will affect the maceration process. The lower the water content, the easier it is to withdraw the sample's active substance because the solvent easily penetrates the sample cell wall without interference from water molecules.

\section{Sample Extraction}

Binahong leaf antioxidant test begins with preparing a sample extract with $96 \%$ ethanol using the maceration method. The extraction results obtained dark green extract. The extract was filtered, then the filtrate was evaporated using a rotary evaporator to remove the solvent to obtain a thick extract weighing $0.94 \mathrm{~g}$ $(1.063 \%)$. The amount of the active compound content of a sample is related to the yield value. If the yield obtained is large, the active compound content will also increase. The high bioactive compounds in a sample are indicated by the high yield value produced.

\section{Phytochemical Test}

Phenolic test

A positive result is indicated in phenol testing by forming a dark blue color when reacted with $1 \% \mathrm{FeCl}_{3}$. Binahong leaf ethanol extract showed positive results indicated by a change in color from yellow to dark blue. The test results showed that the ethanol extract of binahong leaves contained phenolic compounds. The hydroxyl groups in phenolic compounds can react with $\mathrm{FeCl}_{3}$ to form dark blue complexes [11].

\section{Flavonoid test}

To determine the presence or absence of flavonoid compounds presence in the ethanol extract of binahong leaves, testing was carried out using the Shinoda test, namely by reacting the extract with $1 \% \mathrm{HCl}$ powder and $\mathrm{Mg}$ powder. The formation of yellow color indicates a positive test [13]. The test results showed that the ethanol extract of binahong leaves contained flavonoids.

\section{Tannin test}

In the tannin test, the ethanol extract of binahong leaves reacted with $1 \% \mathrm{FeCl}_{3}$ showed positive results, marked by a change in color from green to brown and frothy. The test results showed that the ethanol extract of binahong leaves contained tannin compounds. Tannins will form complex compounds with the $\mathrm{Fe}^{3+}$ ion as the central atom. Tannins contain $\mathrm{O}$ atoms which have lone pairs that can coordinate with the central atom. The $\mathrm{Fe}^{3+}$ ion in the above reaction binds three tannins with two donor atoms, namely the $\mathrm{O}$ atoms in the 4' and 5' dihydroxy positions, so that six lone pairs can be coordinated to the central atom. Atoms $\mathrm{O}$ at 4' and 5' dihydroxy positions have the lowest energy in forming complex compounds [16].

\section{Alkaloid test}

Testing for the presence of alkaloid compounds in a sample was carried out using Mayer's reagent. The ethanol extract of binahong leaves showed positive results, indicated by a color change from white to pink. Mayer's reagent contains potassium iodide and mercuric chloride, producing alkaloid potassium, a white precipitate. The white precipitate is thought to be a complex alkaloid potassium compound. Potassium iodide, which is added excess, will form potassium tetraiodomercurate (II) [17]. The test results showed that the ethanol extract of binahong leaves contained alkaloid compounds.

\section{Determination of the maximum DDPH wavelength \\ Determination of the maximum} wavelength of DDPH is carried out to determine the wavelength required by the $\mathrm{DPPH}$ solution to achieve maximum absorption. The determination of wavelength was carried out using $96 \%$ ethanol blank. The maximum absorbance obtained was 0.736 in the $517 \mathrm{~nm}$ wavelength range. The wavelength corresponds to the maximum wavelength of the DPPH, which is $400-600 \mathrm{~nm}$. Furthermore, the maximum wavelength of DPPH was used in determining the antioxidant activity of binahong leaf ethanol extract. 
Determination of DPPH Free Radical Counter Activity

Calibration curve

Before determining the activity of the DPPH free radical scavenger of binahong leaf ethanol extract, a calibration curve was made to test the linearity of the sample. Based on the calculation results, the data presented in Table 1 and Figure 1 are obtained.

Table 1. The activity of DPPH free radical scavenger of quercetin

\begin{tabular}{cccc}
\hline No & $\begin{array}{c}\text { Quercetin } \\
\text { concentration } \\
(\mathrm{ppm})\end{array}$ & Absorbance & $\begin{array}{c}\% \\
\text { Inhibition }\end{array}$ \\
\hline 1 & 2.5 & 0.451 & 27.84 \\
2 & 5 & 0.342 & 45.28 \\
3 & 10 & 0.256 & 59.04 \\
4 & 15 & 0.122 & 80.48 \\
5 & 20 & 0.025 & 96.00 \\
6 & 25 & 0.020 & 96.80 \\
& DPPH + Ethanol & $\mathbf{0 . 6 2 5}$ & \\
\hline
\end{tabular}

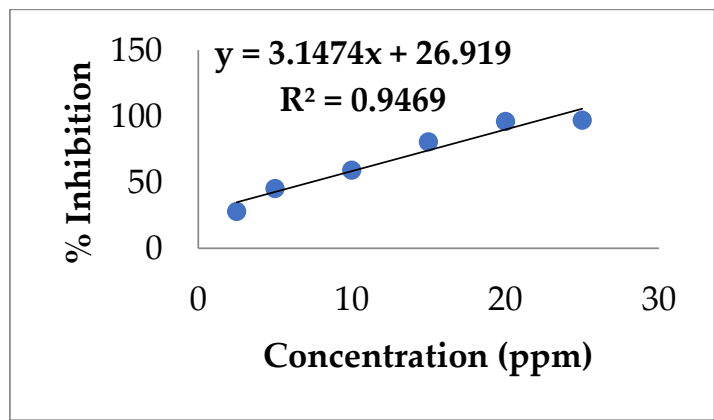

Figure 1. Standard curve of quercetin DPPH free radical scavenging activity

Determination of DPPH free radical scavenging activity was expressed by $\mathrm{IC}_{50}$ value using quercetin control. The measurements using UV-Vis spectroscopy at a wavelength of $517 \mathrm{~nm}$ obtained each concentration's absorbance value. The absorbance value was used to calculate \% inhibition and $\mathrm{IC}_{50}$ quercetin. Based on Table 1 and Figure 1, it can be seen that the increase in quercetin concentration means the higher the ability to ward off DPPH free radicals. From the calculation, the $\mathrm{IC}_{50}$ quercetin value was $46.88 \mu \mathrm{g} / \mathrm{mL}$.
Results of determining DPPH free radical scavenging activity

The antioxidant activity of binahong leaf ethanol extract was tested using the DPPH method. DPPH radical is an organic compound containing unstable nitrogen with strong absorbance at a wavelength of $517 \mathrm{~nm}$. The presence of antioxidant activity from the sample results in a color change from purple to yellow. This change occurs when DPPH free radicals are captured by antioxidants and release hydrogen atoms to capture stable DPPH-H. Qualitatively, the ethanol extract of binahong leaves contains phenolic compounds, flavonoids, alkaloids, and tannins which can donate electrons to ward off free radicals.

The quantitative antioxidant activity test was carried out by measuring the free radical scavenger of a compound with an antioxidant activity using UV-Vis spectrophotometry. Thus will be known the activity of reducing free radicals is expressed by the value of $\mathrm{IC}_{50}$. The $\mathrm{IC}_{50}$ value is defined as the test compound's concentration that can reduce free radicals by $50 \%$. The smaller the $\mathrm{IC}_{50}$ value, the higher the free radical scavenging activity. Specifically, a compound is a powerful antioxidant if the $\mathrm{IC}_{50}$ value is $<50 \mathrm{ppm}, 50-100 \mathrm{ppm}$ strong, 100-150 ppm medium, 150-200 ppm weak, and very weak $>200$ ppm.

Binahong leaf ethanol extract showed an increase in $\%$ inhibition per concentration. The percentage of inhibition was obtained from the difference in the absorbance of the control and the sample's absorbance. The activity of the DPPH free radical scavenger of binahong leaf ethanol extract is presented in Table 2.

Table 2. The activity of DPPH free radical scavenger of binahong leaf ethanol extract

\begin{tabular}{cccc}
\hline & Sampel & \multicolumn{2}{c}{ Average } \\
\cline { 3 - 4 } No & $\begin{array}{c}\text { Concentration } \\
\text { (ppm) }\end{array}$ & Absorbance & $\begin{array}{c}\% \\
\text { Inhibition }\end{array}$ \\
\hline 1 & 10 & 0.615 & 1.75 \\
2 & 20 & 0.606 & 3.27 \\
3 & 30 & 0.588 & 6.06 \\
4 & 40 & 0.574 & 8.38 \\
5 & 50 & 0.562 & 10.29 \\
6 & 60 & 0.530 & 15.20 \\
7 & 70 & 0.487 & 23.52 \\
8 & 80 & 0.371 & 40.78 \\
\hline
\end{tabular}




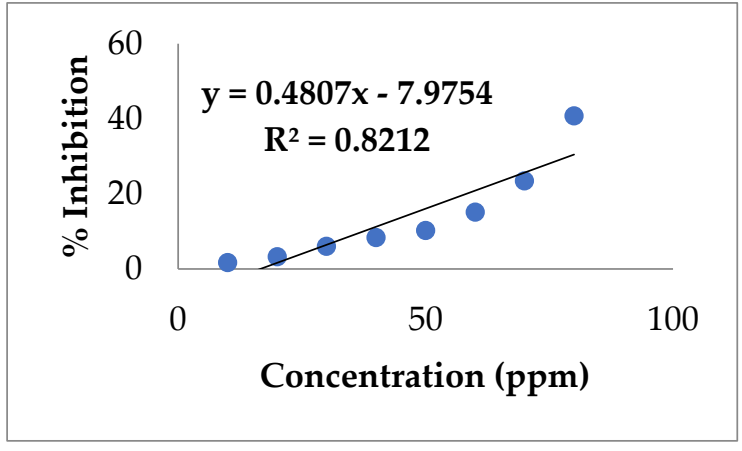

Figure 2. Determination of DPPH free radical scavenging activity of ethanol extract of binahong leaves

Based on Figure 2, the regression equation $\mathrm{Y}=0.4807 \mathrm{x}-7.9754$ and the $\mathrm{IC}_{50}$ value is $87.423 \mu \mathrm{g} / \mathrm{mL}$, which is classified as a strong antioxidant. Compared with the results of a study regarding the antioxidant activity test of the ether fraction from the hydrolysis of binahong leaf infusion, an IC 50 was obtained of $249.31 \mathrm{ppm}$, which means that the antioxidants are fragile [18]. Meanwhile, the antioxidant activity test of binahong leaf ethanol extract with the maceration method obtained an IC 50 $_{50}$ $40.27 \mathrm{ppm}$, which is classified as a powerful antioxidant [14].

\section{Conclusions}

Based on the research results, it can be concluded that the phytochemical test showed that the ethanol extract of binahong leaves contained phenolic compounds, flavonoids, alkaloids, and tannins. The ethanol extract of binahong leaves has a strong antioxidant activity with an $\mathrm{IC}_{50}$ value of $87.423 \mu \mathrm{g} / \mathrm{mL}$.

\section{References}

1. Manoi, F. dan Balittro, Binahong (Anredera cordifolia (Tenore) Steenis) as Medicine. Industrial Crops Research and Development Newsletter. 2009, 15, (1), 3-5.

2. Astuti, S., Sakinah, M., Andayani, R., and Risch, A. Determination of Saponin Compound From Anredera cordifolia (Ten) Steenis Plant (Binahong) to Potensial Treatment for Several Diseases. J. of Agric. Sci. 2011, 3, (4), 224-231. DOI: 0.5539/jas.v3n4p224.
3. Selawa, W. Runtuwene, M. R. J., and Citraningtyas, G. Flavonoid Content and Total Antioxidant Capacity of Binahong Leaf Ethanol Extract [Anredera cordifolia (Ten.) Steenis.]. 2013, PHARMACON Jurnal Ilmiah Farmasi, 2, (01), 18-22.

4. Blaszczyk, A., Augustyniak A., and Skolimowski, Review Article, Ethoxyquin: An Antioxidant Used in Animal Feed. I. J. of Food Sci. 2013, Article ID 585931, 1-12. http://dx.doi.org/10.1155/2013/585931

5. Baiano A., and del Nobile M.A. Antioxidant Compounds from Vegetable Matrices: Biosynthesis, Occurrence, and Extraction Systems. Crit. Rev. Food Sci. Nutr. 2015, 56, 2053-2068. DOI: 10.1080/10408398.2013.812059.

6. Karundeng, M. and Aloanis, A. A., Free Radical Scavenging Analysis of Ethanol Extract of Banyan Fruit (Ficus benjamina Linn.). 2018. Fullerene Journ. of Chem, 3, (2), 37-39. DOI: https://doi.org/10.37033/fjc.v3i2.36.

7. Souhoka, F. A., Hattu, N., and Huliselan, M. Antioxidant Activity Test of Methanol Extract of Kesumba Keling (Bixa orellana L) Seeds. 2019, Indo. J. Chem. Res., 7, (1), 25-31. DOI: https://doi.org/10.30598//ijcr.2019.7fas.

8. Djamil, R., Wahyudi, P.S., Wahono, S., and Hanafi, M. Antioxidant Activity of Flavonoid From Anredera cordifolia (Ten) Steenis Leaves. 2012. I. Res J. of Pharm, 3, (9), 241-243.

9. Rizkia P., Jannah A., and Hasanah, H., Antioxidant Effectiveness Test of $70 \%$ Ethanol Extract, Flavonoid Compound Extract and Isolate in Binahong Tuber (Anredera cordifolia (Ten.) Steenis), 2014, ALCHEMY, 3, (2), 154-162.

10. Jiménez, Y. C., García-Moreno, V. M., Igartuburu, J. M., and Barroso, C. C. Simplification of the DPPH Assay for Estimating the Antioxidant Activity of Wine and Wine by-products. 2014, Food Chem, 165, 198-204.

11. Harborne J. B., Phytochemical Methods: A Guide to Modern Methods of Analyzing Plants, Translation from Phytochemical Method, Translator; Padmawinata K., Soediro I., ITB, Bandung. 2006, pp. 127. 
12. Nafisah, M., Tukiran, Suyanto, Hidayati, N., Phytochemical Screening and Layer Chromatography Analysis of Patikan Kebo Plant Extracts (Euphorbia hirta L). 2017, Medicamento, 3, (2), 61-70.

13. Tiwari, P., Kumar, B., Kaur, M., Kaur, G., and Kaur, H., Phytochemical Screening and Extraction: A Review, 2011, I. Pharm. Sci, 1, (1), 98-106.

14. Parwati, N. K. F., Napitupulu M., dan Diah, A. W. M. Antioxidant Activity Test of Binahong Leaf Extract (Anredera cordifolia (Tenore) Steen) with 1,1-Diphenyl-2Picrylhydrazyl (DPPH) Using a UV-Vis Spectophotometer. 2014, J. Akad. Kim. 3, (4), 206-213.

15. Mulyani, W., Idiawati, N., dan Gusrizal, 2013, Antioxidant Activity of n-hexane, Ethyl Acetate, and Methanol Extracts of Chili Orange Fruit Peels (Citrus microcarpa Bunge). 2013, J. Kimia Khatulistiwa, 2, (2), 90-94.

16. Sa'adah, L., Isolation and Identification of Tannin Compounds from Starfruit Leaves (Averrhoa bilimbi 1.). 2010, Skripsi, Universitas Islam Negeri Maulana Malik Ibrahim, Malang.

17. Marliana, S. D., Suryanti, V., dan Suyono, Phytochemical Screening and Thin Layer Chromatography Analysis of Chemical Compounds in Ethanol Extract of Chayote (Sechium edule Jacq. Swartz.) in Ethanol Extract. Biofarmasi, 2005, 3, (1), 26-31.

18. Ardianti, A., Guntarti, A. dan Zainab. Antioxidant Activity Test of Ether Fraction as a Result of Hydrolysis of Binahong Anredera cordifolia (Ten) Steenis Leaf Infusion Using the DPPH (1,1-diphenyl-2picrylhydrazil) Method. 2014, Pharmaciana, 4, (1), 1-8.

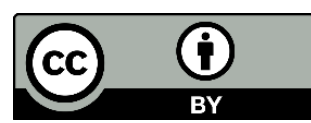

(C) 2021 by the authors. Licensee Fullerene Journal Of Chem. This article is an open access article distributed under the terms and conditions of the Creative Commons Attribution (CC BY) license

(http://creativecommons.org/licenses/by/4.0/). 